\title{
PATTERNS OF EVOLUTION BEFORE EXTINCTION OF TRIASSIC CONODONTS
}

HIRSCH, Francis, Geological Survey of Israel, Malkhe Yisraelstreet 30,95501 Jerusalem, Israel.

After surviving the notorious permian-Triassic boundaryevents, the conodont-bearing animals underwent a number of crisis at the end of Induan, Olenekian, Ladinian, Early Carnian and during Middle Norian to Rhaetian times, before their final extinction at the end of the Triassic. The causes responsible for speciation, radiation and extinction seem possibly related to global sea-level changes, although the Norian-Rhaetian speciations and final extinction of conodonts may have been controlled by competitional pressure at the trophic and reproductive level, possibly by newly appeared taxa, e.g. bonefishes.

Families, defined herein by their multielement-apparatus, are three in number ( 4 genera, 1 being new) in Induan, two ( 8 genera, 6 new) in olenekian, one ( 2 subfamilies, 5 genera, 3 new) in Anisian, Ladinian and Early Carnian before the Carnian crisis, and one ( 1 subfamily, 2 genera, 1 new genus) in Late Carnian, Norian and Early Rhaetian, until extinction of the last conodont taxon at the end of the Rhaetian.

Palaeogeographic distribution of Induan Anchignathodus, Induan - Olenekian Ellisonia and Neospathodus, Induan - Early Rhaetian Neogondolelia and olenekian plativillosus are boreal to equatorial. olenekian Furnishius, parachirognathus, Hadrodontina and Pachycladina are found in cratonic cordilleran and Werfen facies. Latest Olenekian, respectively Anisian to Early Carnian Gladi- and Paragondolella define low-latitude mesopelagic Tethys. Ladinian sephardiella extends from shallow Tethys to Boreal realms, whereas Neogondolella and Pseudofurnishius dwelled respectively in restricted Anisian to Early Ladinian Germanic and semi-open Ladinian sephardic provinces. The specialization of post-Induan taxa into environmental niches became first reduced from the generic to specific level and disappeared entirely in Late Norian and Rhaetian. Latest Carnian - Latest Rhaetian Epigondolella species extended from low (Tethyan) to high (Boreal) latitudes, in pelagic and cratonic facies. Norian species of paragondolella

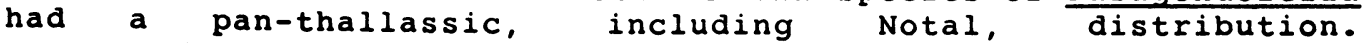
Triassic p-elements always show similar patterns of evolution of the platform and basal cavity as appearance of denticles on platform-edges, development of a free blade and splitting of basal cavity, causing broadening of platform. These characters are lost or abandoned in highly critical periods. Instead, ancestral morphs with reduced platforms, often without apparatus, or early ontogenetic stages, re-appear, from which evolution restarts. Norian-Rhaetian taxa, however, seem to play that scenario backwards, a process reminding of neoteny or paedomorphism. This process is accompanied by the irreversible reduction in the number of species of Late Rhaetian conodonts. 